\title{
Definition of critical summer and fall habitat for bowhead whales in the eastern Canadian Arctic
}

\author{
Benjamin Wheeler ${ }^{1, *}$, Marianne Gilbert ${ }^{2}$, Stephen Rowe $^{3}$ \\ ${ }^{1}$ Hemmera, 1380 Burrard St., Suite 250, Vancouver, British Columbia V6Z 2H3, Canada \\ ${ }^{2}$ Stantec, 4370 Dominion St., 5th floor, Burnaby, British Columbia V5G 4L7, Canada \\ ${ }^{3}$ Integrated Informatics Inc., 268 Duckworth Street, St. John's, Newfoundland A1C 5W1, Canada
}

\begin{abstract}
Bowhead whale Balaena mysticetus critical habitat was identified as a key information gap by the Eastern Arctic Bowhead Whale Recovery Team. To fill this gap, data on eastern Canadian Arctic (ECA) bowhead whales and their habitat were collected and analyzed. We selected governmental, private, and historical whaling bowhead location datasets which differed in temporal and spatial extent, sample size, and quality. Sufficient data were available only for the 'reduced-ice' period (June to October) and pooled by month. Data for 6 ecogeographical variables (EGVs) were integrated into a geographical information system (GIS): sea surface temperature, chlorophyll, ice, depth, slope, and distance to shore. A monthly ecological niche factor analysis was performed for each whale and EGV dataset to determine habitat suitability in the ECA. Eleven habitat suitability models were produced, and a composite map of predicted high suitability habitat, for all 5 months, was developed. Twenty-one areas within the ECA were identified as highly suitable habitat and ranked according to analytical confidence. Six critical habitats were identified and are supported by recent scientific evidence and Inuit knowledge. Recently, the population estimate, conservation status, and management of the Eastern Canada-West Greenland bowhead population have changed dramatically (bowhead whales of this population also inhabit the ECA). In parallel, evidence of ecological change from climate warming has increased and associated loss of sea ice is anticipated to increase interactions between bowheads and anthropogenic activity. As envisioned by the recovery team, this study provides resource managers with a timely tool for population recovery, conservation, and protection.
\end{abstract}

KEY WORDS: Eastern Canadian Arctic $\cdot$ Bowhead whale $\cdot$ Critical habitat - Ecological niche modeling $\cdot$ Ecological niche factor analysis $\cdot$ Habitat suitability $\cdot$ Species recovery $\cdot$ Management . Climate change

Resale or republication not permitted without written consent of the publisher

\section{INTRODUCTION}

Bowhead whales Balaena mysticetus, like many large baleen whales, were decimated by historic commercial whaling (Burns et al. 1993), primarily during the 19th century. Bowheads of the Eastern Canada-West Greenland Arctic (EC-WG) population (abundance of $6344 ; 95 \%$ CI 3119 to 12 906) are currently designated as 'special concern' (COSEWIC
2009). Not long ago, this group was comprised of 2 separate populations (Hudson Bay-Foxe Basin and Davis Strait-Baffin Bay), both of which are considered 'threatened' (COSEWIC 2005) and number 345 and 3000, respectively. Amalgamation and de-listing of these groups is predicated upon telemetry studies, a recent aerial survey abundance estimate (Cosens et al. 2006, Dueck et al. 2006, IWC 2008, COSEWIC 2009), and increasing numbers suggested by Inuit 
knowledge (referred to as Inuit Qaujimajatuqangit [IQ], NWMB 2000) and surveys off Greenland (Heide-Jørgensen et al. 2007). Under the Canadian Species at Risk Act (SARA), federal recovery efforts (Recovery Team and Recovery Strategy) are not legally required for populations designated as 'special concern,' and the Eastern Arctic Bowhead Recovery Team (Recovery Team) disbanded. Prior to doing so, the Recovery Team set the identification of critical habitat $(\mathrm{CH})$ as an important recovery objective (Eastern Arctic Bowhead Recovery Team 2007). Defining $\mathrm{CH}$ for any species is challenging, but even more so for transitory animals such as bowhead whales which spend the majority of time underwater and often in ice environs. Studies indicate that ECWG bowheads travel large distances (Dueck et al. 2006, Ferguson et al. 2010a), may be spread over thousands of kilometers, and may segregate by size, sex, or reproductive status (Finley 2001). To legally define $\mathrm{CH}$ in Canada under SARA, a high degree of scientific information and certainty, similar to that known for the highly studied Bering-Chukchi-Beaufort (BCB) population ('endangered,' Allen \& Angliss 2009; and 'special concern,' COSEWIC 2009), now estimated at over 10000 whales (COSEWIC 2009, Koski et al. 2010), is required. As specified by SARA, we must know what habitat is necessary for the survival and recovery of the population. This level of information, about an area spanning their large range, does not exist for EC-WG bowheads (and may not exist for some time). Hence, a secondary objective of this study was to provide resource managers with a practical and scientifically defensible definition of $\mathrm{CH}$ that could be used based on currently available information.

Largely in concert with seasonal sea ice distribution, bowheads undertake extensive migrations from southern wintering grounds to northern summer feeding habitats (Finley 2001). Apart from ice (Ferguson et al. 2010a), other ecogeographical variables (EGVs) believed to influence bowhead whale distribution include oceanography (e.g. water depth/ bathymetry, and temperature; Thomson et al. 1986, Finley 2001, Harwood et al. 2010), prey availability (Thomson et al. 1986, LGL Ltd. 1987, Finley 2001, Harwood \& Smith 2002), and predators (NWMB 2000, Finley 2001, Laidre et al. 2008, Ferguson et al. 2010b). Given their large range, it is expected that eastern Arctic bowhead whales are exposed to large variations of such conditions.

Habitat models incorporating large spatio-temporal habitat variability have been successfully developed for cetaceans (e.g. Gregr \& Trites 2001, Cañadas et al. 2005, Redfern et al. 2006). To meet the study objectives, we applied ecological niche modeling to available bowhead locations and EGVs in the Eastern Canadian Arctic (ECA). Ecological niche factor analysis (ENFA) combines known locations with relevant EGVs to predict the ecological requirements (habitat suitability) and distribution of a species. One of the main advantages of this method is that it can be used with presence-only data (Hirzel et al. 2002). We explored, validated, and described hypotheses regarding habitat suitability and critical bowhead habitat. Similarly, we present a practical definition of $\mathrm{CH}$.

\section{METHODS}

We used a data-driven modeling approach to identify $\mathrm{CH}$, which involved: (1) locating and compiling bowhead position data, (2) locating EGV data that may influence bowhead distribution, (3) conducting habitat modeling, and (4) defining and determining $\mathrm{CH}$.

\section{Whale locations}

We consulted published and grey literature and bowhead specialists for available bowhead locations in the ECA. Data obtained varied by source, sighting method, effort availability, and spatial extent. We considered only data sources that included a large number of whale locations and spanned large portions of the ECA. Of these, 1 provided presence/ absence data (government aerial surveys), 2 provided presence-only data (private sector surveys and historical whaling), and 1 provided spatial polygons of IQ (Nunavut Wildlife Management Board, NWMB). Each dataset possessed advantages and disadvantages making their combined use in this study complementary. As sample sizes were low during winter and spring, we used only data from June to October. We pooled the data monthly to account for bowheads' highly migratory and seasonal behavior. Whale locations (single or groups) were imported into the ArcGIS geographical information system (GIS) for modeling and validation.

Fisheries and Oceans Canada (DFO) conducted aerial surveys in August from 2002 to 2004 (Cosens et al. 2006). These surveys varied in location and spatial coverage, and no whales were sighted in 2004. In total, 93 whale locations were recorded (Fig. 1) along the survey tracks in 2003. 


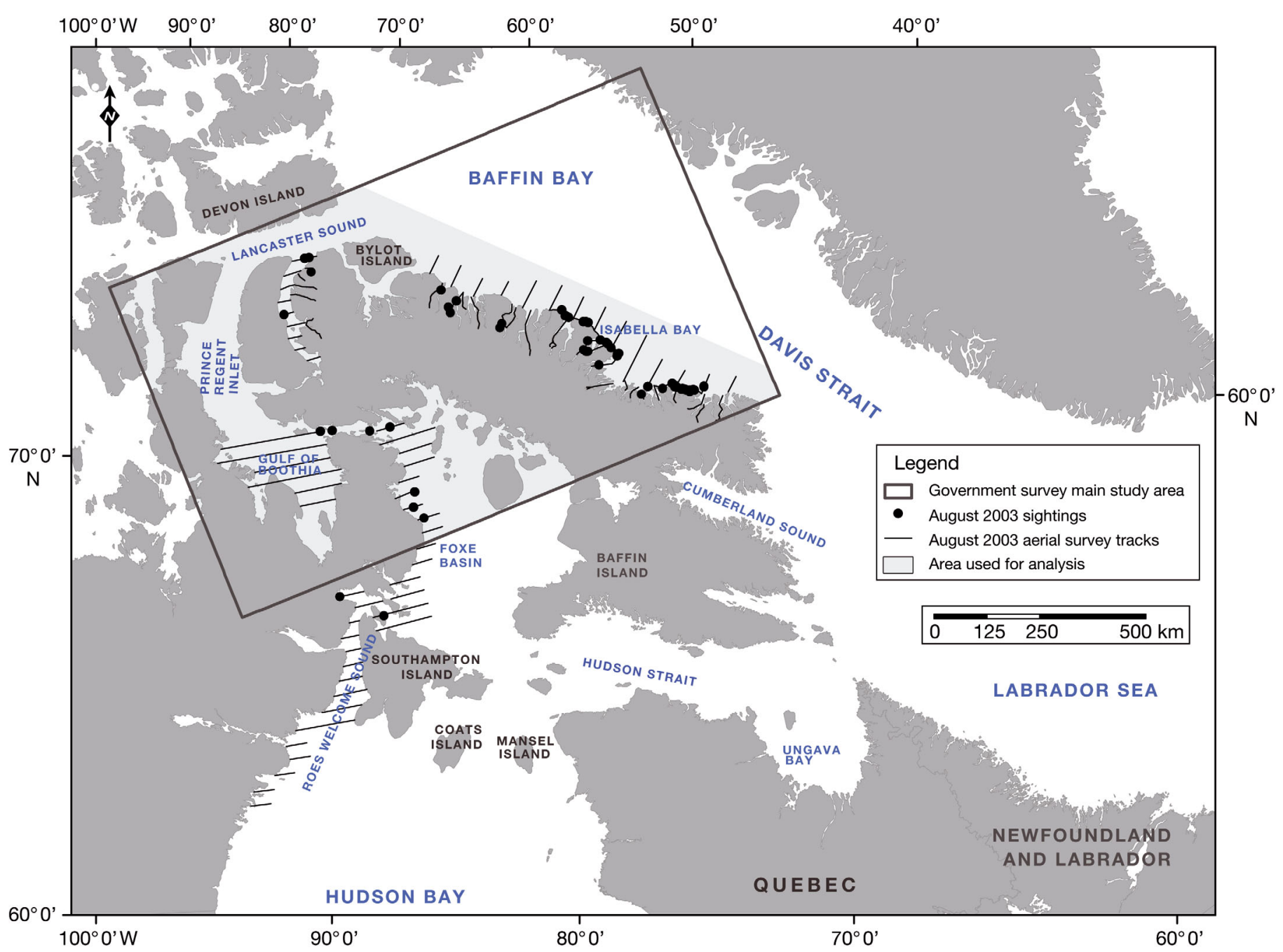

Fig. 1. Balaena mysticetus. Bowhead sighting locations and survey effort from August 2003 government aerial surveys (adapted from Cosens et al. 2006) and study area used for habitat modeling

We obtained private sector survey data for 1976 , 1978, 1979, 1981, and 1982 (LGL Ltd. unpubl. data). Surveys were aerial, shore, and vesselbased, and covered a large portion of the northern ECA (Fig. 2). Shore-based surveys were made from high vantage points and therefore covered large areas. Track information (i.e. effort and associated absences) was not readily available and therefore not included.

We obtained whale kill locations from reviews of historic whaling records (Ross \& MacIver 1982, Reeves et al. 1983, Reeves \& Mitchell 1990, Reeves \& Cosens 2003). The compiled dataset contained 2100 whale locations: 1150 locations from Reeves \& Cosens (2003), 20 from Reeves \& Mitchell (1990), and 930 from Reeves et al. (1983). Of these points, 1922 had the temporal information (month and year) required for monthly analyses (Fig. 3). This dataset spanned 373 yr, from 1615 to 1988 (Fig. 3).

\section{Ecogeographical variables and study areas}

Environmental and physical factors are known to influence cetacean distribution (Thomson et al. 1986, Murison \& Gaskin 1989, Laidre et al. 2008, Rogachev et al. 2008, Ashjian et al. 2010). Available EGV data included sea ice, chlorophyll $a(\mathrm{chl} a$; as a proxy for prey availability), sea surface temperature (SST; as a proxy for productivity), distance to shore (related to predator avoidance; Finley 2001), depth, and slope (as a proxy for upwelling and productivity). While these EGVs are likely correlated to some degree, ENFA is insensitive to correlations because, like 


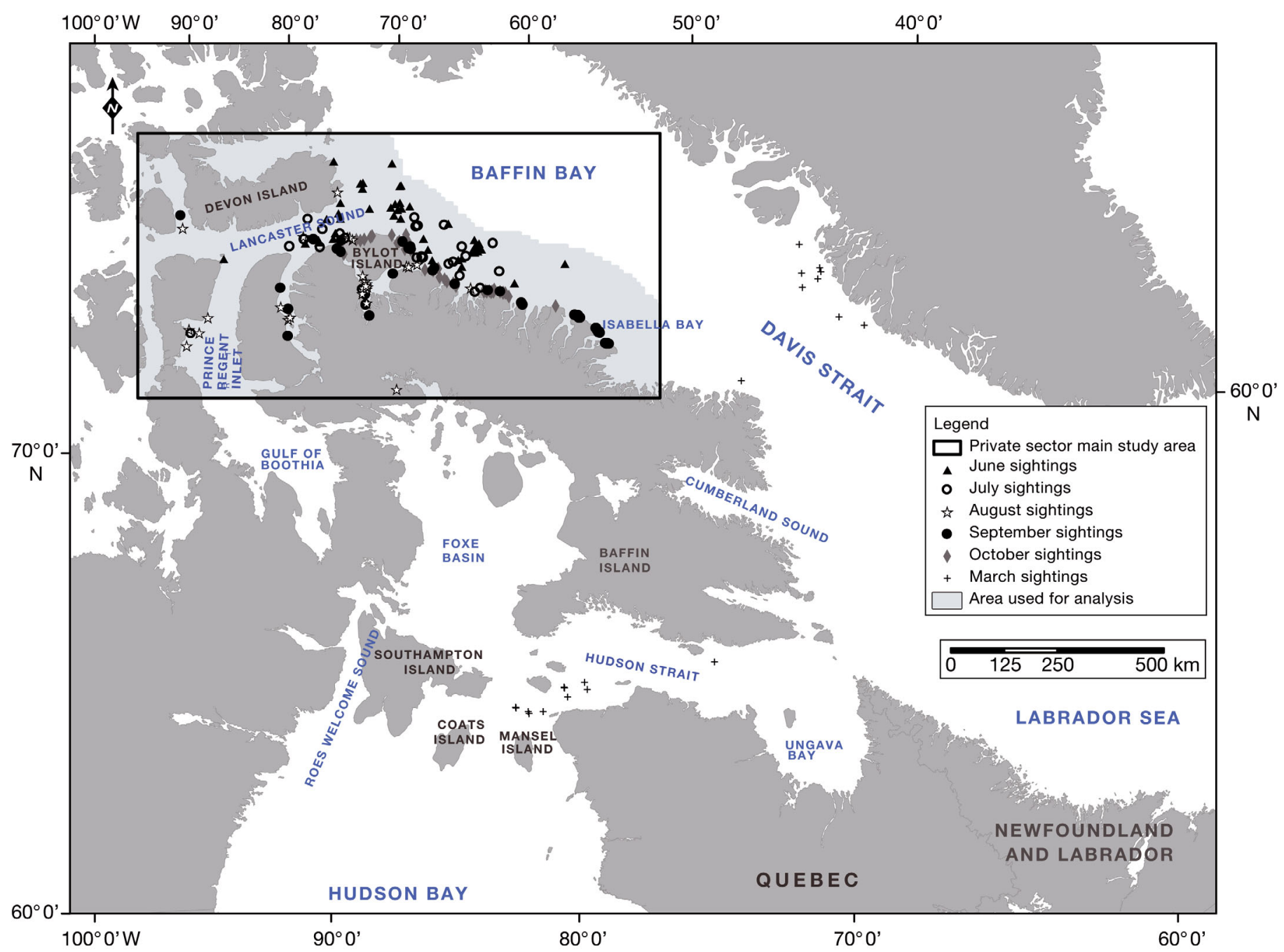

Fig. 2. Balaena mysticetus. Bowhead sighting locations obtained from private sector surveys conducted in 1976, 1978, 1979, 1981, and 1982 (LGL Ltd. unpubl. data) and area used for habitat modeling

principal component analyses, the EGVs are summarized into uncorrelated factors with an ecological meaning (Hirzel et al. 2002).

EGV data were converted to a grid format. A grid cell size of $10 \times 10 \mathrm{~km}$ was used. This size was sufficiently small to take advantage of the resolution of the EGVs $\left(<10 \times 10 \mathrm{~km}^{2}\right)$ and large enough to take into account precision of whale location data. It was also consistent with that used by Gregr \& Trites (2001), which was based on precision of historic whaling data.

SST $\left({ }^{\circ} \mathrm{C}\right)$ and $\mathrm{chl} a\left(\mathrm{mg} \mathrm{m}^{-3}\right)$ data were acquired from the MODIS-Aqua Level 3, $4 \mathrm{~km}$ binned product offered from 'Ocean Color Web' (Feldman \& McClain 2006). Ice data were obtained from the Canadian Ice Service (2006). Depth and slope data were derived from bathymetry obtained from the 2-Minute Grid- ded Global Relief Data (ETOPO2v2; US Department of Commerce 2006). The slope of the sea floor and the distance to shore for each sighting were calculated using ArcGIS.

Where possible, we selected EGV data from dates when locations of whales were collected. We used the averaged $8 \mathrm{~d}$ SST and chl a maps (Feldman \& McClain 2006) most closely corresponding in time with the week of government aerial surveys for the analysis of government survey data. Pre-averaged monthly SST and chl a data over the period of 2002 or 2003 through to 2006 were used to match the longer-term whaling and private sector datasets (Feldman \& McClain 2006). Similarly, to best match government survey data, we acquired weekly composite ice charts of the ECA for the August 2003 survey period. For the 


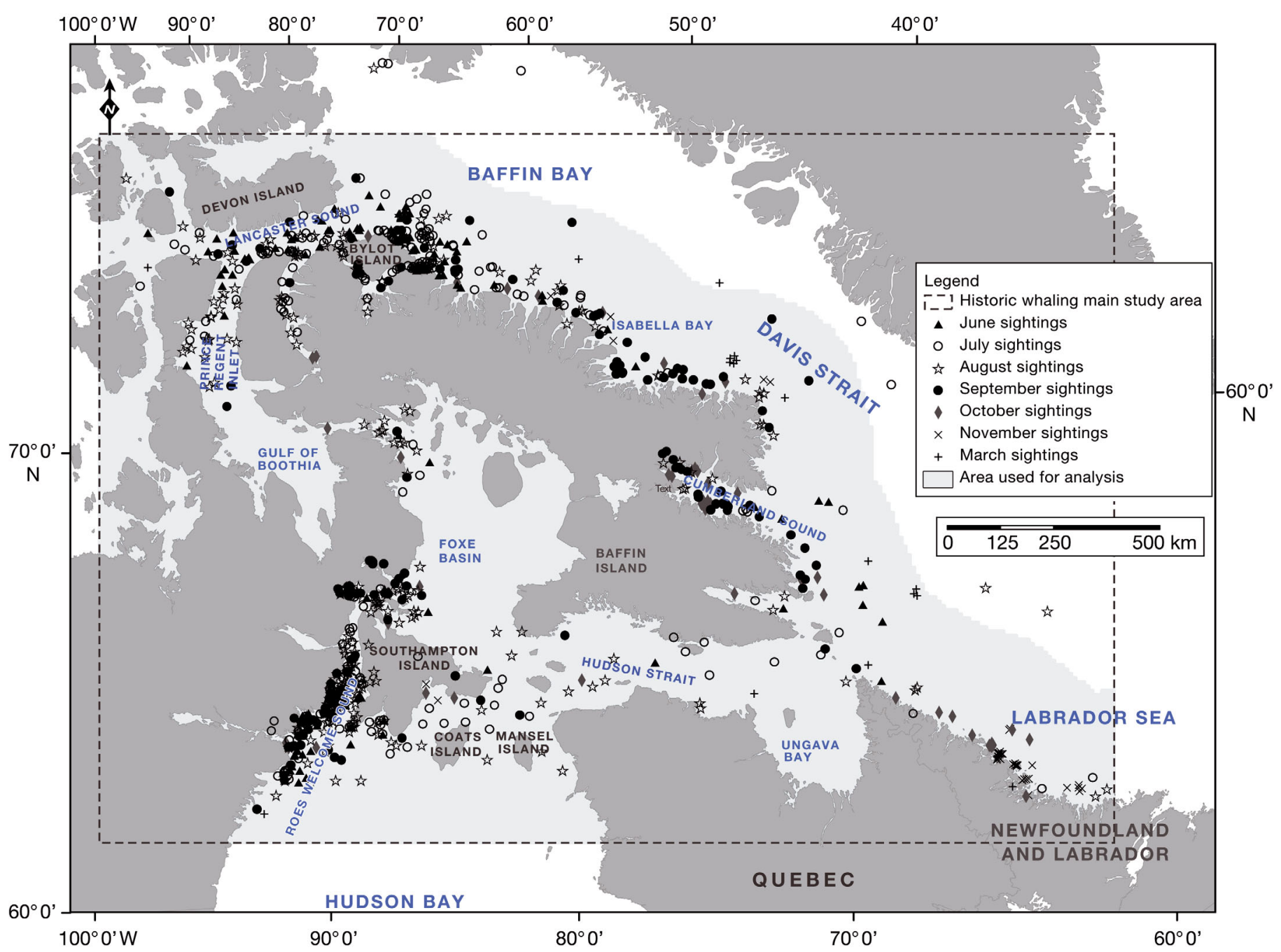

Fig. 3. Balaena mysticetus. Bowhead kill locations from whaling records from 1615 to 1988 (adapted from Reeves et al. 1983, Reeves \& Mitchell 1990, and Reeves \& Cosens 2003) and area used for habitat modeling

historical whaling and private sector datasets, we used regional ice data for 1971 to 2000 (monthly medians).

We combined whale locations and EGV data into 1 grid-based GIS dataset per model. Each grid cell was assigned a summary of the input variables for the area within the cell (i.e. whale presence and average conditions of each EGV within the cell; see Jacques Whitford AXYS Ldt. 2007 for details on data processing).

Three study areas, corresponding to each bowhead location dataset, were identified (Figs. 1 to 3). Commensurate with the chosen modeling tool (below), analyses within each study area focused primarily near whale locations and where survey effort was likely. This was to exclude regions far offshore and avoid analytical biases associated with ENFA theory.

\section{Habitat suitability modeling}

We used ENFA to build the models because it best suited our objective and the attributes of the whale location and EGV data. All whale position and EGV datasets were converted and imported into the software Biomapper (Hirzel et al. 2006a) for analysis. Where possible, EGVs were normalized using the Box-Cox standardizing algorithm (which looks for the best transformation; Hirzel \& Arlettaz 2003).

ENFA extracted mutually independent factors. Significant factors were determined by comparing the factors' contribution to MacArthur's broken-stick distribution (Hirzel et al. 2002). These factors were used as dimensions in the environmental space for habitat suitability (HS) modeling (Hirzel et al. 2002). We used Biomapper's distance geometric mean algo- 
rithm to compute similarity coefficients between each location and the most suitable conditions (HS index). We chose this algorithm over the median algorithm because it has been shown to have better predictive power (Hirzel \& Arlettaz 2003).

We evaluated the importance of the individual EGVs to the model predictions in terms of their contribution to marginality and specialization factors. Marginality indicates how EGV data associated with whale positions differ from global data within the analysis area (Hirzel et al. 2002). Values range between 0 and 1 . Values close to 0 indicate that sightings occurred in average conditions relative to available conditions. Specialization represents the niche breath relative to global conditions (Hirzel et al. 2002) and is the inverse of tolerance. Tolerance values range between 0 and 1 , with a high value (close to 1), indicating that a species is not too selective of its environmental conditions (Hirzel et al. 2002).

ENFA is a strictly descriptive method and cannot extract causality relations. However, it does provide important cues about preferential conditions (Hirzel et al. 2002). By looking at marginality factor coefficients on each EGV in the ENFA matrix (of each model), we determined for which EGV bowhead whales selected conditions farthest from average, and whether they selected values lower or higher than average. Specialization factors also provided insight into which EGV had the most restricted range of suitable values for bowhead whales.

We validated the models using a jack-knife procedure to compute a confidence interval around the predictive accuracy of the HS model. The process consisted of partitioning the bowhead location datasets into 10 equal size subsets, and using 1 subset for validation instead of model calibration. This process was repeated for each of the 10 subsets. From the subsets, the number of grid cells that fell within a number of HS bin ranges was computed. Each bin represented a portion of the map $\left(A_{i}\right)$ area and contained a proportion of the validation cells $\left(N_{i}\right)$. Model fit $(F)$ was evaluated using the 'Boyce index' (Boyce et al. 2002), which looks at areaadjusted frequency of the bins $\left(F_{i}=N_{i} / A_{i}\right)$. A random map would provide $F$ values of approximately 1 (random frequency line) whereas a good model would result in low $F$ values for low HS values and high $F$ values for high HS values. Relative model quality was determined as 'low,' 'moderate,' or 'high' by evaluating the Boyce indices (using bins and continuous; Hirzel et al. 2006b), associated variance, and the shape of the $F$ curves.
Table 1. Balaena mysticetus. Global marginality, specialization, and tolerance values from ecological niche factor analyses (ENFA) performed on 11 monthly bowhead location datasets in the eastern Canadian Arctic from June to October. See 'Methods: Habitat suitability modeling') for definitions of marginality, specialization, and tolerance

\begin{tabular}{|lccc|}
\hline Dataset & Marginality & Specialization & Tolerance \\
\hline June & & & \\
$\quad$ Private sector & 0.503 & 1.930 & 0.518 \\
Whaling & 0.447 & 1.332 & 0.751 \\
July & & & \\
$\quad$ Private sector & 0.664 & 2.220 & 0.451 \\
Whaling & 0.496 & 1.299 & 0.770 \\
August & & & \\
$\quad$ Private sector & 0.920 & 4.281 & 0.234 \\
Whaling & 0.537 & 1.274 & 0.785 \\
Government & 0.599 & 1.930 & 0.518 \\
$\quad$ survey 2003 & & & \\
September & & & \\
$\quad$ Private sector & 0.926 & 2.842 & 0.352 \\
Whaling & 0.494 & 1.709 & 0.585 \\
October & & & \\
Private sector & 0.805 & 2.196 & 0.455 \\
Whaling & 0.810 & 1.672 & 0.598 \\
\hline
\end{tabular}

\section{HS synthesis}

Based on the cross-validation results, we reclassified each of the HS maps using 4 different suitability classes according to bin ranges (unsuitable: 0-25; marginal: 26-50; suitable: 51-75; highly suitable: 76-100). We chose only the highest HS class to integrate with other data sources and results. Commensurate with best modeling practices from the United Nations' Food and Agriculture Organization (FAO 2008), we then combined model results from governmental, private, and whaling data into monthly high suitability habitat maps. Each model's highly suitable habitat was given the same weight within the study area.

To further synthesize the results produced by the HS models, we integrated all 5 monthly combined high suitability habitat maps. Each cell within the ECA was assigned a rank from 0 to 5 for the number of months it was coded as highly suitable habitat. Cell ranking was color coded and displayed as an overall composite map.

\section{Assumptions}

Due to the variability in available data (quantity, quality, spatial accuracy and coverage, and temporal coverage), several underlying assumptions were required: 
- whale presence in the ECA, in summer, is largely dictated by food availability

- distribution of bowhead prey is related to oceanographic processes (through increases in productivity or physical concentration of prey)

- bowheads are not typically found within large ice pans or consolidated ice in the 'reduced-ice' period

- whale positions obtained are of sufficient accuracy to match with EGV data and predict large-scale trends

- spatial patterns of whale positions obtained are representative of the actual whale distribution and not an artifact of whaling or survey efforts

- recent environmental conditions are representative of the entire period for which bowhead locations are available (i.e. historical whaling data)

- bowhead whale habitat use is not influenced by changes in population size.

\section{RESULTS}

\section{Models produced}

Eleven analyses were performed on whale location datasets and associated EGV data for the period of June to October. All EGVs were used in the analyses except in October, when either ice or SST was excluded due to missing data. A monthly model was produced for each monthly whaling and private sector dataset. An additional model was produced for August with the government dataset.

\section{Interpretation of monthly trends and factors}

Marginality and specialization values peaked in August and September (Table 1). Marginality values for all analyses (June to October) ranged from 0.447 to 0.926 (Table 1), indicating that suitable habitat differed considerably from average conditions within study areas. Specialization values suggested that bowheads are somewhat restricted in habitat use compared to the habitat available in the study areas (Table 1). Tolerance values indicated that bowheads were observed in areas deemed as unsuitable habitat (Table 1).

Model results strongly suggested that bowheads select less than average distances to shore, ice concentration, and depth from June to October (Table 2). The majority of models (7 of 11) suggested that greater than average slopes are selected by bowheads, but most of the values were small with many values $<0.1$, suggesting that this trend may not be significant. The majority of models (7 of 10) indicated that bowheads select greater than average

Table 2. Balaena mysticetus. Marginality results from ecological niche factor analyses (ENFA) showing bowhead locations in greater than $(>)$ or less than $(<)$ average conditions in the study area of each dataset for each ecogeographical variable (EGV), and primary EGVs governing bowhead habitat marginality and specialization in the eastern Canadian Arctic. SST: sea surface temperature; chl a: chlorophyll a. Blanks: no data available

\begin{tabular}{|c|c|c|c|c|c|c|c|c|}
\hline \multirow[t]{2}{*}{ Dataset } & \multirow[t]{2}{*}{ Distance } & \multirow[t]{2}{*}{ Slope } & \multirow[t]{2}{*}{ Depth } & \multirow[t]{2}{*}{ Chl a } & \multirow[t]{2}{*}{ SST } & \multirow[t]{2}{*}{ Ice } & \multicolumn{2}{|c|}{ - Primary EGV for } \\
\hline & & & & & & & marginality & specialization \\
\hline \multicolumn{9}{|l|}{ June } \\
\hline Private & $<$ & $<$ & $<$ & $>$ & $>$ & $<$ & Ice & Distance \\
\hline Whaling & $<$ & $<$ & $<$ & $<$ & $<$ & $<$ & Distance & Ice \\
\hline \multicolumn{9}{|l|}{ July } \\
\hline Private & $<$ & $>$ & $>$ & $>$ & $>$ & $>$ & Distance/SST & Chl $a$ \\
\hline Whaling & $<$ & $<$ & $<$ & $>$ & $>$ & $<$ & Distance & Chl a \\
\hline \multicolumn{9}{|l|}{ August } \\
\hline Private & $<$ & $<$ & $<$ & $>$ & $<$ & $<$ & Distance & Ice \\
\hline Whaling & $<$ & $>$ & $<$ & $>$ & $<$ & $<$ & Distance & SST \\
\hline Government & $<$ & $>$ & $<$ & $<$ & $>$ & $<$ & Distance & Chl a \\
\hline \multicolumn{9}{|l|}{ September } \\
\hline Private & $<$ & $>$ & $<$ & $>$ & $>$ & $<$ & Distance & Ice \\
\hline Whaling & $<$ & $>$ & $<$ & $<$ & $>$ & $<$ & Distance & Ice \\
\hline \multicolumn{9}{|l|}{ October } \\
\hline Private & $<$ & $>$ & $<$ & & & $>$ & Distance & Ice \\
\hline Whaling & $<$ & $>$ & $<$ & $>$ & $>$ & & Distance & Chl a/SST \\
\hline Total > & 0 & 7 & 1 & 7 & 6 & 2 & & \\
\hline Total $<$ & 11 & 4 & 10 & 3 & 4 & 8 & & \\
\hline
\end{tabular}


chl a concentration. Model results did not demonstrate a strong preference for greater or less than average SSTs from June to October.

The primary EGV governing marginality (i.e. that with the highest coefficient for marginality) was distance from shore (10 of 11 models); however, no one variable appeared to mostly restrict the range of bowheads based on the specialization factor explaining the most information from June to October. Five models suggested that ice is the most restrictive EGV, 4 suggested it is chl $a$, and at least 1 suggested it is SST. This indicates that whales were usually located within a narrow range of ice concentrations and somewhat narrow range of chlorophyll and SST values compared to average values.

\section{Model validation and performance}

Model quality varied between months and datasets and is likely related to whale location and EGV data used, and their quality (i.e. sample size and degree of temporal overlap; Table 3). The private sector data produced high-quality models for July and October only (October had a much greater sample size), whereas the whaling data produced high-quality models for August and September (2 of the months

Table 3. Balaena mysticetus. Cross-validation results or model 'fit' ( $F=$ Boyce index $\pm \mathrm{SD}$ ) from ecological niche factor analyses performed on 11 bowhead location datasets in the eastern Canadian Arctic, and qualitative determinations on model quality

\begin{tabular}{|lrrc|}
\hline Dataset & $F(4$ bins $)$ & $F$ (continuous) & $\begin{array}{c}\text { Relative } \\
\text { model quality }\end{array}$ \\
\hline June & & & \\
Private & $-0.016 \pm 0.549$ & $-0.114 \pm 0.442$ & Low \\
Whaling & $0.692 \pm 0.414$ & $0.588 \pm 0.494$ & Moderate \\
July & & & \\
Private & $0.667 \pm 0.094$ & $0.622 \pm 0.046$ & High \\
Whaling & $0.700 \pm 0.508$ & $0.654 \pm 0.396$ & Moderate \\
August & & & \\
Private & $0.520 \pm 0.439$ & $0.492 \pm 0.388$ & Moderate \\
Whaling & $0.880 \pm 0.240$ & $0.813 \pm 0.310$ & High \\
Govt. survey & $0.867 \pm 0.094$ & $0.559 \pm 0.293$ & High \\
2003 & & & \\
September & & & \\
Private & $-0.320 \pm 0.610$ & $-0.164 \pm 0.378$ & Low \\
Whaling & $0.920 \pm 0.098$ & $0.842 \pm 0.074$ & High \\
October & & & \\
Private & $0.877 \pm 0.173$ & $0.570 \pm 0.285$ & High \\
Whaling & $-0.086 \pm 0.573$ & $-0.008 \pm 0.538$ & Low \\
\hline
\end{tabular}

with the highest sample sizes). Models within each month differed slightly in quality.

Overall, models showed good performance in identifying high-suitability habitat. However, in several cases, variance in the data (SD) was high, thereby reducing model quality. Generally, the continuous Boyce index indicated lower overall model quality than the Boyce index using bins. When looking at the predicted/expected $(P / E)$ ratio curves, most models ( 7 of 11) did well at predicting habitats in the highest HS category (mean and SD clearly above the $P / E=1$ ) .

\section{HS synthesis}

The models predicted HS bowhead habitat in nearly all coastal areas of the ECA for at least 1 month (Fig. 4). Large regions of HS habitat were identified for 2 months, and discrete clusters of areas were identified as HS for 3 or more months. Clusters of cells with 3 or more months were delineated visually into discrete areas for discussion purposes (Fig. 4).

\section{DISCUSSION}

\section{Definition of $\mathbf{C H}$}

We defined 'highly suitable habitat' after Hirzel et al. (2002) as those areas predicted to be used by bowheads more often than expected by chance, relative to habitat available in the environment.

We identified $\mathrm{CH}$ for bowhead whales primarily between June and October, within 20 to $100 \mathrm{~km}$ of most ECA shorelines. Though not a novel conclusion, our study provides increased resolution within this general region. The flexibility and adaptability of the species' habitat requirements are unknown, and it is not clear whether all currently used areas are critical to survival. However, it is possible to identify highly suitable habitat important to the survival of bowheads (when defined as those areas predicted to seasonally support whales and those ecosystem processes on which bowheads rely). This study used 3 datasets of known bowhead locations (nearly 1700 over 5 months), and it is reasonable to assume that this broad inclusion captured areas that support bowhead nursery, resting, feeding, and migratory habitat. We argue that this is sufficient to produce a reasonable description of $\mathrm{CH}$ and adopt that term for the highly suitable habitat areas identified by our analysis. 


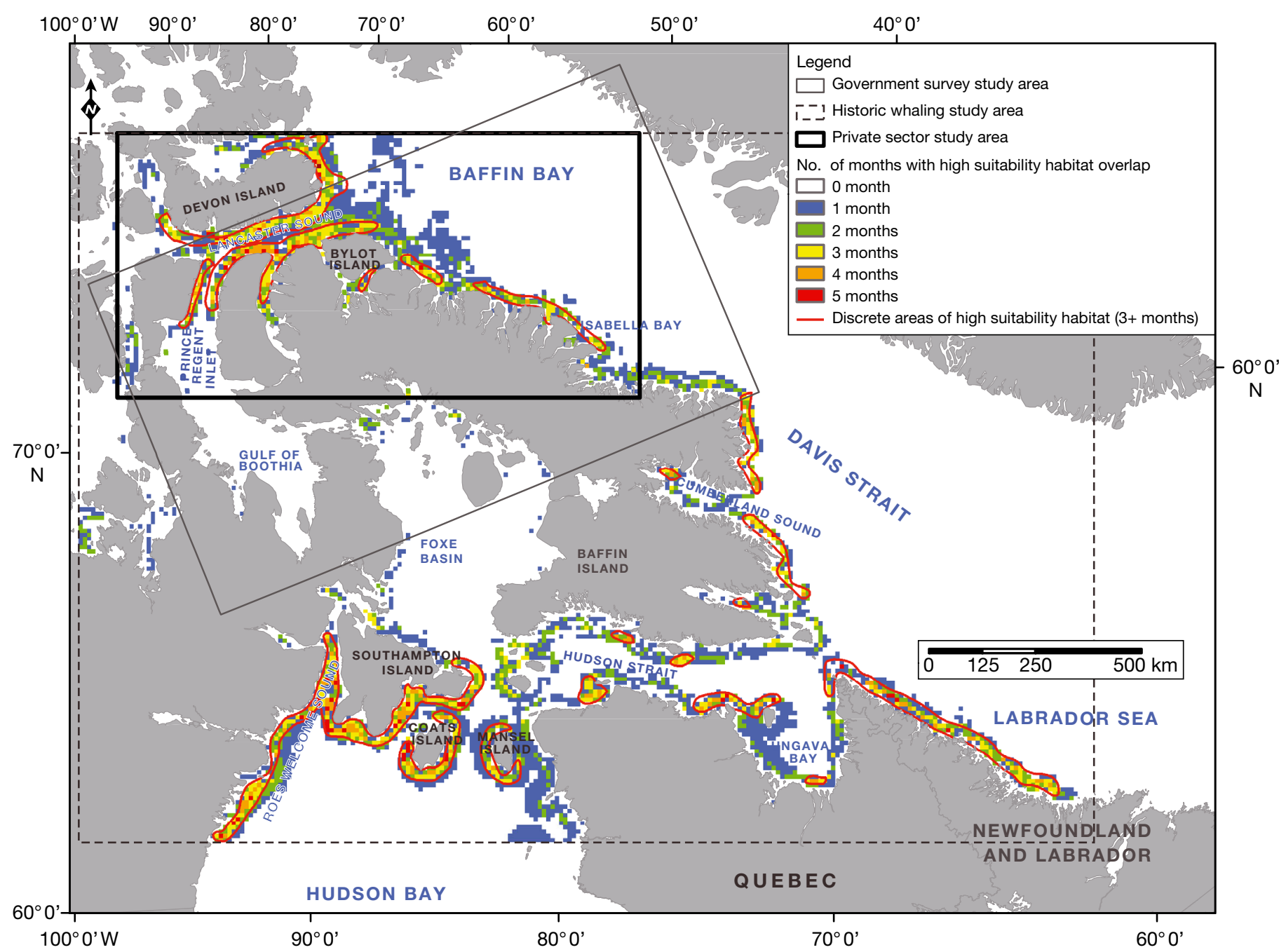

Fig. 4. Balaena mysticetus. Composite highly suitable habitat map from June to October; discrete clusters (3, 4, or 5 months) of highly suitable habitat outlined in red; produced by ecological niche factor analyses (ENFA) of 3 bowhead location datasets in the eastern Canadian Arctic

To realize the potential of habitat information from the 3 whale location datasets, we assumed the more models that predicted the same highly suitable habitat (monthly), the more important it is. Predicted areas of $\mathrm{CH}$ for the majority of the reduced-ice period ( 3 or more of the 5 months) can be considered the most important for the persistence of the population (for feeding or other reasons).

\section{Areas identified as $\mathrm{CH}$}

Our analysis identified 21 discrete areas within the ECA as $\mathrm{CH}$ for the majority of the reduced-ice period ( 3 or more of the 5 months; Fig. 5). Of these 21 areas, 6 (Areas 2, 4, 5, 6, 7, 8) were located within the com- bined study areas of all 3 location datasets (all 11 models contributed information in the same region; Fig. 5). Two of the $21 \mathrm{CH}$ areas (Areas 1 and 3) were located within the combined study area of 2 of the 3 datasets ( 10 of the 11 models contributed information in the same region). The majority (13) of the 21 areas (Areas 9 to 21) were within the study area of only 1 whale location dataset (historic whaling data; only 5 of the 11 models contributed information in this area). We assigned a level of confidence in the predictions of $\mathrm{CH}$ based on model contribution.

Identification of $\mathrm{CH}$ solely based on data collected from few whales for 1 month of 1 year does not instill confidence. Hence, where all 11 models overlapped spatially, our confidence is highest that the 6 discrete areas (Areas 2, 4, 5, 6, 7, and 8 in Fig. 5) can be consid- 


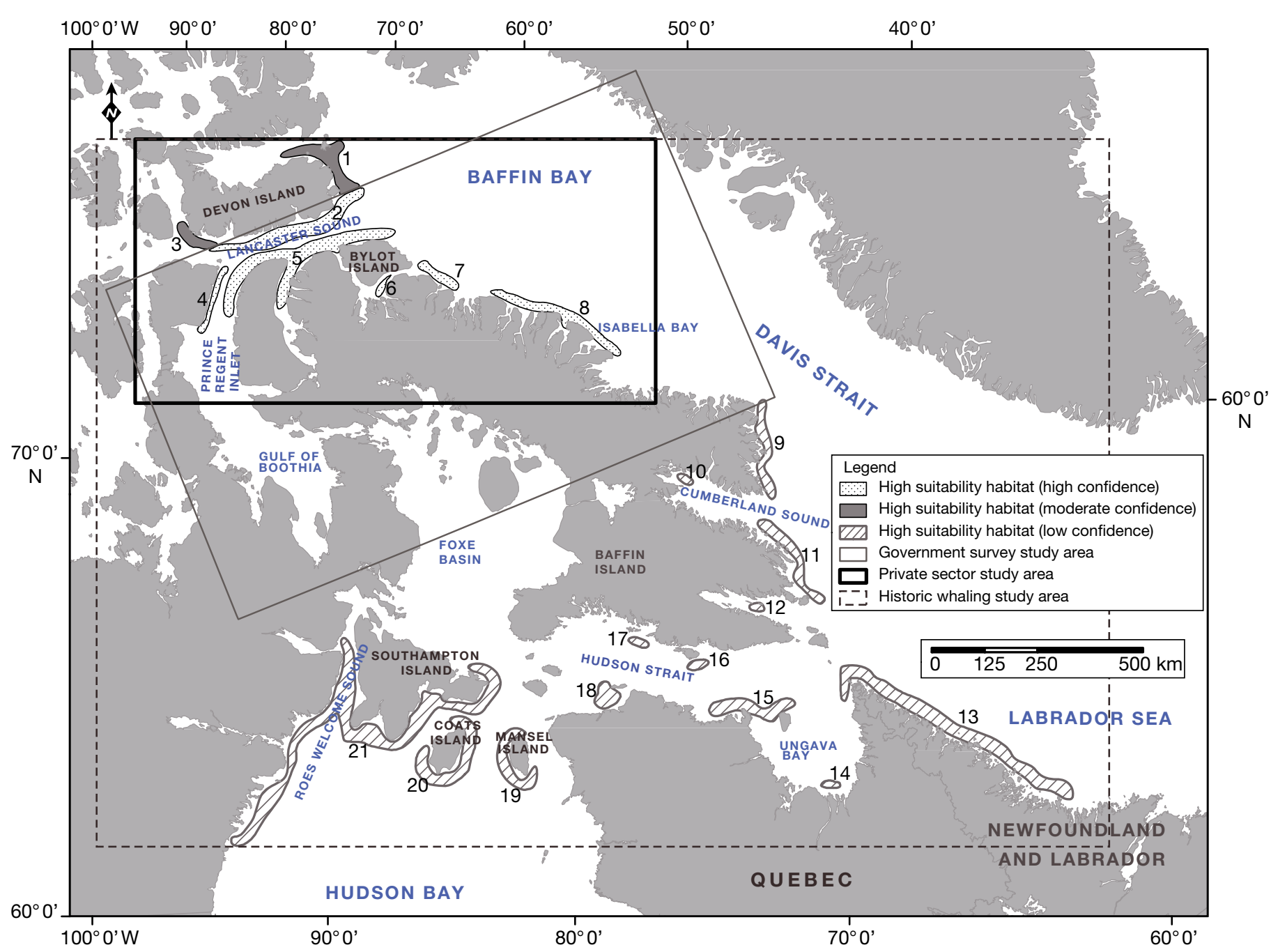

Fig. 5. Balaena mysticetus. Discrete areas of highly suitable habitat identified for 3 or more months from June to October in the eastern Canadian Arctic (by analytical confidence) produced by ecological niche factor analyses (ENFA) of 3 bowhead location datasets and associated ecogeographical variables

ered bowhead $\mathrm{CH}$. Similarly, based on overlap, we have moderate confidence that 2 of the areas (Areas 1 and 3 in Fig. 5) constitute $\mathrm{CH}$. Our confidence is lower that the 13 remaining areas are $\mathrm{CH}$, given the lack of spatial overlap between the 3 different models.

\section{Support for $\mathbf{C H}$ identification}

To compare our predictions to what is known about bowhead whale distribution, we consulted recent literature and IQ (see Fig. 6 for summary). Lancaster Sound (Area 2 and part of Area 5; Fig. 5) has long been recognized as bowhead habitat. Our results suggest that this region is important from June to October (not only at the eastern spring floe-edge, as suggested by Koski \& Davis 1979). Bowheads enter Lancaster Sound from early May until early August (Davis \& Koski 1980), and according to Finley (2001), this area represents an important spring migration corridor. A single male bowhead was tracked along the south coast of Lancaster Sound in 2004 (Dueck et al. 2006), and unpublished data by Heide-Jørgensen (in Dueck et al. 2006) also indicate use of the southern Lancaster Sound coast in August. Dueck \& Ferguson (2008) and Ferguson et al. (2010a) noted that bowheads migrate along the southern coast of Lancaster Sound but do not linger in the sound. The IQ data suggest that bowheads migrate through Lancaster Sound in the spring and can also be found here in early fall (NWMB 2000). Identification of the south coast of Lancaster Sound as $\mathrm{CH}$ is therefore well sup- 


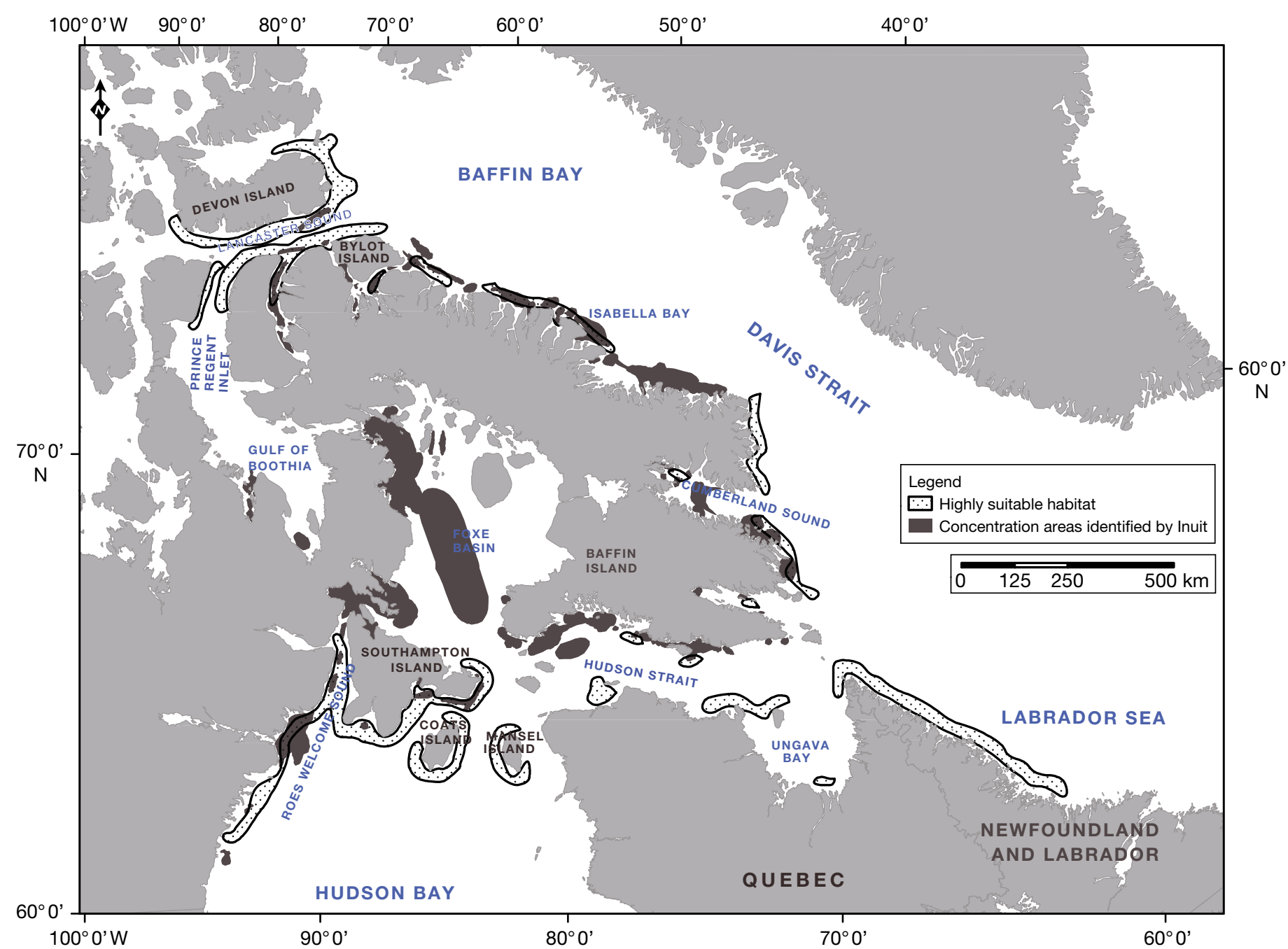

Fig. 6 Balaena mysticetus. Comparison of highly suitable habitat predicted by ecological niche factor analyses (ENFA) with bowhead concentration areas identified by Inuit in Nunavut, Canada, in late spring, summer, and early fall (adapted from NWMB 2000)

ported. As implied by IQ, the north coast and some central portions of the sound (Area 2; Fig. 5) are also important to bowheads; however, recent scientific evidence is limited to 1 bowhead track (HeideJørgensen et al. 2003). We found no evidence of systematic surveys of Lancaster Sound, and relatively few bowhead whales have been instrumented with satellite tags. Hence, on the basis of IQ and this study, we suggest the northern region of the sound may also be important habitat.

$\mathrm{CH}$ identified off the east coast of Somerset Island and northern Prince Regent Inlet (Area 4 and a portion of Area 5; Fig. 5) is related primarily to migration (Finley 1990, 2001, NWMB 2000, Iacozza \& Barber 2003, Reeves \& Cosens 2003, Dueck et al. 2006, Heide-Jørgensen et al. 2006). Bowhead $\mathrm{CH}$ was identified in Admiralty Inlet (portion of Area 5; Fig. 5). IQ supports this finding (spring to early fall; NWMB 2000), as do 2003 aerial surveys (Cosens et al. 2006) and 2006 tagging studies (Heide-Jørgensen et al. 2006). However, aerial surveys of Admiralty Inlet flown in 2004 did not detect bowheads, demonstrating high seasonal variability. $\mathrm{CH}$ near Pond Inlet (Areas 6 and 7; Fig. 5) is well supported by recent scientific and Inuit evidence, most likely (and regularly) in spring (Koski \& Davis 1979, Reeves et al. 1983, NWMB 2000, Finley 2001, Heide-Jørgensen et al. 2006).

The stretch of $\mathrm{CH}$ from Cape Adair to Henry Kater Peninsula (Area 8; Fig. 5) encompasses Isabella Bay, a previously (e.g. Finley 1990, 2001, NWMB 2000), and recently (WWF 2003, Hansen et al. 2009) identi- 
fied important late-summer and fall habitat. Both feeding areas at Isabella Bay (Aqviq and Kater troughs; Finley et al. 1993) were identified as important habitat for 3 months. Fall visual surveys from Cape Adair (Davis \& Koski 1980) suggest $\mathrm{CH}$ in this region is related to migration.

$\mathrm{CH}$ southwest of Devon Island (Area 3; Fig. 5), identified here with moderate confidence, is not well supported by literature or IQ (although telemetry studies showed bowhead use in October/November; unpubl. data from Heide-Jørgensen in Dueck et al. 2006). Evidence indicates that highly suitable habitat northeast of Devon Island (Area 1; Fig. 5) exists in the spring (Koski \& Davis 1979, unpubl. data from HeideJørgensen in Dueck et al. 2006).

Thirteen areas were identified (with low confidence) as $\mathrm{CH}$. These areas are located in southerly regions of the ECA and the identified range for this population (COSEWIC 2009). Telemetry studies and IQ (NWMB 2000) confirm the Cumberland Peninsula region (Area 9; Fig. 5) as a migratory route (Dueck et al. 2006, Ferguson et al. 2010a). IQ supports the identification of $\mathrm{CH}$ in the Lemieux Islands (Area 10; Fig. 5), Frobisher Bay (Area 11; Fig. 5), near Kimiruit (Big Island; Area 15; Fig. 5), and Roes Welcome Sound (Area 20; Fig. 5). Aerial surveys (Cosens \& Innes 2000) and telemetry studies (Dueck et al. 2006) also confirm bowhead presence in Roes Welcome Sound.

We found no corroborating IQ or scientific evidence for identified $\mathrm{CH}$ in northern Quebec and Labrador (Areas 13-15, 18 and 19; Fig. 5). This may be because bowheads no longer use these areas or surveys and IQ studies (reduced-ice period) were not conducted.

\section{Other important habitat}

There were several regions where our models did not capture expected $\mathrm{CH}$ during the reducedice season. $\mathrm{CH}$ near Igloolik was identified for 1 and 2 months, but not for 3 or more months. Similarly, identified $\mathrm{CH}$ in northern Prince Regent Inlet did not include distinct areas used by bowhead whales in southern Prince Regent Inlet and Gulf of Boothia (Dueck \& Ferguson 2008, Ferguson et al. 2010a).

Discovery of numerous bowheads offshore from Pond Inlet (and near the eastern entrance to Lancaster Sound; Koski \& Davis 1979) sets an expectation regarding $\mathrm{CH}$. Our models did capture this region as $\mathrm{CH}$ but only for 1 month (June; see Fig. 5).

\section{Assumptions and limitations}

Interpretation of the predictive modeling results must take into account the nature and assumptions of the input information (whale location and EGV data) and model theory.

Of the bowhead location data used in this analysis, the more difficult to interpret are the historic whaling records. Limitations include the lack of survey effort (and knowledge of bowhead absence), low precision, and lack of concurrent, high-resolution EGV data (e.g. ice conditions, SST, chl a). The first 2 limitations are addressed by ENFA theory. According to Compton (2004), historic whaling data may include some positional inaccuracies which may lead to overestimation of the size of highly suitable habitat, underestimation of the marginality and specialization, and overestimation of tolerance. However, ENFA is designed specifically for use with datasets that are of potentially low or unknown quality and those lacking adequate absence data, such as opportunistic sightings data and museum records (Hirzel et al. 2001, 2002, Reutter et al. 2003). Use of historic whaling records may be further complicated by restrictions in whaling from ice conditions, nationality, vessel type (sail versus steam), and changing harvest effort over time. Theoretically, these factors do not diminish the value of the point-source location data (e.g. a bowhead was found at the recorded kill location and therefore may have occupied a suitable habitat). The large sample size and spatial and temporal range of this dataset, compared to other available location data, dictate that this information be included in ECWG bowhead studies. In accordance with the above, and because of the violation of a key analytical assumption (that EGV conditions at the time of the whale kills over $370 \mathrm{yr}$ ago are the same as presentday conditions), the historic whaling model results, on their own, were treated with lower confidence.

Perceived positive attributes of the governmental aerial bowhead surveys (greater accuracy, presence and absence information, numerous, modern, highly systematic, and large spatial coverage) were not realized in this study. From 3 yr of regional governmental aerial surveys, only results from 2003 were used (due to weather-related limitations and small sample sizes: 22 whales in 2002 and 0 in 2004). The surveys were also limited in spatial and temporal (August only) coverage, in all years.

Private sector survey data were useful. Not only did they have a reasonable sample size (249 whale locations), but they also provided good yearly and monthly (June to October) coverage. Further, initia- 
tion of remote sensing technology coincided with these data, and hence we can be reasonably confident that the EGV data were appropriately matched. ENFA does not take into account effort. A preliminary generalized linear model (GLM) for the presence/absence government whale location dataset compared to models produced by ENFA and other known whale location datasets suggested that ENFA performed better than a GLM in predicting suitable whale habitat (Jacques Whitford AXYS Ldt. 2007). Therefore, incorporation of effort and associated absence data from private sector surveys would not have changed our results substantially.

Although it was not possible to numerically integrate IQ on bowheads with other datasets, meaningful comparison with ENFA results was possible. In fact, IQ data were the only other information source of comparable spatial range to historic whaling data available to verify model predictions in the southern ECA, making the IQ data invaluable to the model assessment.

\section{Limitations of observational data}

As discussed, our analyses did not identify all expected $\mathrm{CH}$ in the reduced-ice period. This may in part be due the presence of ice. Regions that regularly have large concentrations of ice (like Prince Regent Inlet) would not have had SST or chl a data, limiting predictive abilities. Regions with greater variability in ice concentration (i.e. much of the ECA) were captured by our models. Our definition of $\mathrm{CH}$ excludes areas important to bowheads for less than 3 months. Hence, some areas that are highly seasonal (e.g. offshore of Pond Inlet), by definition, would not have been included as $\mathrm{CH}$. Areas potentially important to bowheads for less than a month, and from November to May, also would not have been identified. For these reasons, our analysis likely underestimates bowhead $\mathrm{CH}$ in the ECA.

\section{Ecological interpretation}

While a detailed discussion of bowhead habitat was beyond the scope of our study, we uncovered some interesting habitat correlations. Our models indicate that bowheads are relatively specialized in terms of habitat use (based on EGV and areas included). Peaks in marginality and specialization in August and September are likely indicative of good feeding conditions. At the spatial scale studied, whales used open-water habitat as it became increasingly available over the summer/fall. This is consistent with what is seen in the Beaufort Sea where summer bowheads are associated with the ice front through July but in August and September are found in open water off the continental shelf (Richardson et al. 1985, Harwood et al. 2010). While bowheads are thought to be strongly associated with sea ice (Ferguson et al. 2010a), this was not apparent in our study, where the importance of ice varied more by dataset and spatial scale than monthly. This is presumably due to the spatial and temporal scales at which ice cover is measured and averaged: at our relatively coarse resolution, we could not capture the patchiness in ice cover apparent at higher resolutions.

Bowheads appear to select shallow areas closer to shore. This may be due to predator avoidance (Finley 2001), an artifact of correlation with other EGVs, or biases in whale location data. Selection of habitat with greater slopes than average in most models, particularly from August to October, suggests selection of upwelling conditions favorable for feeding. This would be similar to conditions observed in the Beaufort Sea (Thomson et al. 1986).

Trends in SST and chl a concentration were similar in nature. $\mathrm{CH}$ was predicted where these variables were greater than the average conditions earlier in the 'reduced-ice' season. These variables progressively approached average conditions, as the season progressed. This trend is likely correlated to ice reduction, increases in water temperature, and primary productivity. Our study suggests that more habitat becomes suitable overall as ice disappears and that specific SST and chl a concentrations are not as important.

\section{Implications for management}

Dramatic changes in the population estimate, conservation status, and management of EC-WG bowheads have taken place over a relatively short time. Canadian bowhead resource managers have made these changes based on relatively limited (e.g. few aerial surveys), non-quantitative (e.g. IQ), and often imprecise (e.g. the re-analysis of 2002 abundance estimate; IWC 2008, COSEWIC 2009) information.

These management changes have occurred as evidence has been mounting for increasing unidirectional climate warming leading to circumpolar reductions in sea ice and increased air and sea temperatures (Laidre et al. 2008, Atkinson 2009). Hence, 
the need for precautionary management and conservation of EC-WG bowheads and their habitat is greater now than it was even 5 yr ago. Bowheads are predicted as moderately sensitive to climate change with low population size, migration, and low population growth rates as primary sensitivity drivers (Laidre et al. 2008).

Further reductions in sea-ice coverage from predicted future climate warming (Johannessen et al. 2004) will also facilitate access to resources and increased human activity. Changes to Canadian policy on Arctic vessel reporting (suggesting anticipated increases in Arctic vessel activity; Transport Canada 2010) and the discovery of oil in Baffin Bay in 2010 (BBC 2010) may signal that such increases have begun. Hence, significant pressure on the EC-WG population from ecological change is expected to be intensified by new threats relating to shipping, commercial fishing, and oil and gas exploration and development.

As anticipated by the Recovery Team, this study provides a broad and timely tool for resource managers and population recovery planning. Results from this science-based tool are repeatable, founded on ecological theory, best available input data (on bowhead locations and EGVs), and habitat modeling technology. The 6 predicted bowhead $\mathrm{CH}$ (with highest confidence) are supported by recent scientific evidence (to the degree it exists) and IQ. Two of these 6 habitats are under consideration for federal protection (e.g. proposed Lancaster Sound National Marine Conservation Area and Niginganiq [Isabella Bay] National Wildlife Area). Hence, in addition to ice-associated bowhead summer/fall habitat in Prince Regent Inlet (as identified by Dueck \& Ferguson 2008, Ferguson et al. 2010a), a starting point for future bowhead habitat conservation includes Admiralty Inlet, northern Prince Regent Inlet, coastal areas close to Pond Inlet, and from Cape Adair to Isabella Bay.

\section{Future studies}

The addition of bowhead telemetry data and other private sector aerial survey data would strengthen this analysis and potentially support higher-resolution studies. Collection of additional whale location data with concurrent information on EGVs in the $\mathrm{CH}$ identified here would prove useful for improved management. Incorporation of regional climatologies (including wind data) into the analysis may help us understand how other EGVs (currents, freshwater input, and ice movement) may influence EC-WG bowhead distribution. Our study analyzed data on a monthly basis (primarily as this was how it was available). Future studies may consider lumping months into broader seasons to identify further ecological relationships and broad habitat use.

As mentioned, climate change is predicted to place pressure on EC-WG bowhead recovery. Habitat modeling provides researchers with a mechanism to predict changes in bowhead $\mathrm{CH}$ from climate change by exploring altering environmental conditions, such as SST and chl a concentration. The 'holy grail' of habitat modeling would be to provide resource managers with 'real-time' annual predictions of important summer/fall bowhead habitat. With continued testing, validation, and integration of high-quality bowhead location and comprehensive EGV data, this may one day be possible.

Acknowledgements. WWF Canada funded this study. We acknowledge A. Kautaq (Clyde River), G. Ross, B. Koski, S. Cosens, L. Dueck, H. Cleator, M.P. Heide-Jørgensen, J. Iacozza, and J. Higdon, members of the Recovery Team. We thank P. Ewins, R. Lim, and E. Gregr for their contributions and support. K. Finley's passion and discovery of eastern Arctic bowhead biology was a large source of inspiration behind this study.

\section{LITERATURE CITED}

Allen BM, Angliss RP (2009) Bowhead whale (Balaena mysticetus): Western Arctic stock. NOAA-TM-AFSC-223. Available at www.nmfs.noaa.gov/pr/pdfs/sars/ak2010 whbh-arw.pdf

Ashjian CJ, Braund SR, Campbell RG, George JC and others (2010) Climate variability, oceanography, bowhead whale distribution, and Iñupiat subsistence whaling near Barrow, Alaska. Arctic 63:179-194

Atkinson N (2009) A 10400-year old bowhead whale (Balaena mysticetus) skull from Ellef Ringes Island, Nunavut: implications for sea-ice conditions in High Arctic Canada at the end of the last glaciations. Arctic 62:38-44

BBC (British Broadcasting Corporation) (2010) Cairn Energy strikes oil off Greenland. www.bbc.co.uk/news/ukscotland-11381281 (accessed 15 January 2011)

> Boyce MS, Vernier PR, Nielsen SE, Schmiegelow FKA (2002) Evaluating resource selection functions. Ecol Model 157:281-300

Burns JJ, Montague JJ, Cowles CJ (1993) The bowhead whale. Spec Publ No. 2. Society for Marine Mammalogy. Allen Press, Lawrence, KS

Cañadas A, Sagarminaga R, De Stephanis R, Urquiola E, Hammond PS (2005) Habitat preference modelling as a conservation tool: proposals for marine protected areas for cetaceans in southern Spanish waters. Aquat Conserv 15:495-521

Canadian Ice Service (2006) Canadian Ice Service Arctic regional sea ice charts in SIGRID-3 format. National Snow and Ice Data Center Boulder, CO. Available at www.ec.gc.ca/glaces-ice/ (accessed 10 July 2010) 
Compton RC (2004) Predicting key habitat and potential distribution of northern bottlenose whales (Hyperoodon ampullatus) in the northwest Atlantic Ocean. MSc thesis. University of Plymouth

Cosens SE, Innes S (2000) Distribution and numbers of bowhead whales (Balaena mysticetus) in northwestern Hudson Bay in August 1995. Arctic 53:36-41

Cosens SE, Cleator H, Richard P (2006) Number of bowhead whales (Balaena mysticetus) in the eastern Canadian Arctic, based on aerial surveys in 2002, 2003 and 2004. DFO Can Sci Advis Res Doc 2006/052. Available at www. dfo-mpo.gc.ca/csas-sccs/publications/resdocs-docrech/ 2006/2006_052-eng.htm

COSEWIC (Committee on the Status of Endangered Wildlife in Canada) (2005) COSEWIC assessment and update status report on the bowhead whale Balaena mysticetus in Canada. Committee on the Status of Endangered Wildlife in Canada, Ottawa, ON. Available at www. sararegistry.gc.ca

COSEWIC (2009) COSEWIC assessment and update status report on the Bowhead Whale Balaena mysticetus in Canada. Committee on the Status of Endangered Wildlife in Canada. Ottawa, ON. Available at www. sararegistry.gc.ca

Davis RA, Koski WR (1980) Recent observations of the bowhead whale in the eastern Canadian High Arctic. Rep Int Whaling Comm 30:439-444

Dueck LP, Ferguson SH (2008) Habitat use by bowhead whales (Balaena mysticetus) of the eastern Canadian Arctic. DFO Can Sci Advis Res Doc 2008/082. Available at www.meds-sdmm.dfo-mpo.gc.ca/csas/applications/ Publications

Dueck LP, Heide-Jørgensen MP, Jensen MV, Postma LD (2006) Update on investigations of bowhead whale (Balaena mysticetus) movements in the eastern Arctic, 2003-2005, based on satellite-linked telemetry. DFO Can Sci Advis Res Doc 2006/050. Available at www.dfo-mpo. gc.ca/csas-sccs/publications/resdocs-docrech/2006/2006_ 050-eng.htm

Eastern Arctic Bowhead Recovery Team (2007) Minutes of the Eastern Arctic Bowhead Whale Recovery Team meeting. March 13-14, 2007. Navigator Inn, Iqaluit, Nunavut Department of Fisheries (DFO), Winnipeg

FAO (2008) Fisheries technical guidelines for responsible fisheries, No. 4, Suppl 2, Add 1. FAO, Rome

Feldman GC, McClain CR (2006) Ocean Color Web, MODIS-Aqua, Reprocessing 1.1, NASA Goddard Space Flight Center. Available at http://oceancolor.gsfc.nasa. gov/ (accessed 10 January 2010)

Ferguson SH, Dueck L, Loseto LL, Luque SP (2010a) Bowhead whale Balaena mysticetus seasonal selection of sea ice. Mar Ecol Prog Ser 411:285-297

Ferguson SH, Higdon JW, Chmelnitsky EG (2010b) The rise of killer whales as a major Arctic predator. In: Ferguson S, Losetto L, Mallory M (eds) A little less Arctic. Springer, New York, NY, p 117-136

Finley KJ (1990) Isabella Bay, Baffin Island: an important historical and present-day concentration area for the endangered bowhead whale (Balaena mysticetus) of the Eastern Canadian Arctic. Arctic 43:137-152

Finley KJ (2001) Natural history and conservation of the Greenland whale, or bowhead, in the northwest Atlantic. Arctic 54:55-76

Finley KJ, Fissel DB, Goodyear JD, Ashton HJ (1993) Definition of critical bowhead whale feeding habitat in Baffin
Bay, 1992. Unpubl. report for Supply and Services Canada, Environment Canada, World Wildlife Fund, and Indian Affairs and Northern Development, Ottawa, Ontario, Canada. Available at World Wildlife Fund (Canada), 245 Eglinton Ave. E., Toronto, ON M4P 3J1

Gregr EJ, Trites AW (2001) Predictions of critical habitat for five whale species in the waters of coastal British Columbia. Can J Fish Aquat Sci 58:1265-1285

Hansen RG, Heide-Jørgensen MP, Laidre KL (2009) Recent abundance of bowhead whales in Isabella Bay, Canada. IWC Report SC/62/BRG28. Available at http://iwcoffice.org/_documents/sci_com/SC62docs/SC62-BRG28.pdf

Harwood LA, Smith TJ (2002) Beaufort Sea whales: an overview and outlook. Arctic 55(Suppl):77-93

Harwood LA, Auld J, Joynt A, Moore SE (2010) Distribution of bowhead whales in the SE Beaufort Sea during late summer, 2007-2009. DFO Can Sci Advis Res Doc 2009/111. Available at http://www.dfo-mpo.gc.ca/csassccs/publications/resdocs-docrech/2009/2009_111-eng. htm

Heide-Jørgensen MP, Laidre KL, Wiig $\varnothing$, Jensen MV and others (2003) From Greenland to Canada in ten days: tracks of bowhead whales, Balaena mysticetus, across Baffin Bay. Arctic 56:21-31

Heide-Jørgensen MP, Laidre KL, Jensen MV, Dueck L, Postma LD (2006) Dissolving stock discreteness with satellite tracking: bowhead whales in Baffin Bay. Mar Mamm Sci 22:34-45

Heide-Jørgensen MP, Laidre KL, Borchers D, Samarra F, Stern H (2007) Increasing abundance of bowhead whales in West Greenland. Biol Lett 3:577-580

Hirzel AH, Arlettaz R (2003) Modeling habitat suitability for complex species distributions by environmental-distance geometric mean. Environ Manag 32:614-623

Hirzel AH, Helfer V, Metral F (2001) Assessing habitatsuitability models with a virtual species. Ecol Model 145:111-121

Hirzel AH, Hausser J, Chessel D, Perrin N (2002) Ecological-niche factor analysis: how to compute habitat suitability maps without abundance data. Ecology 83: 2027-2036

Hirzel AH, Hausser J, Perrin N (2006a) Biomapper 3.2. Laboratory of Conservation Biology, Department of Ecology and Evolution, University of Lausanne. Available at www.unil.ch/biomapper

Hirzel AH, Le Lay G, Helfer V, Randin C, Guisan A (2006b) Evaluating the ability of habitat suitability models to predict species presences. Ecol Model 199:142-152

Iacozza J, Barber D (2003) Bowhead habitat relationships in Foxe Basin/Gulf of Boothia, 2003. Marine Science EMSI Inc., Winnipeg

IWC (International Whaling Commission) (2008) Report of the Scientific Committee. J Cetacean Res Manag 10(Suppl):1-74

Jacques Whitford AXYS Ldt. (2007) Determining highly suitable/critical habitat for the eastern Arctic bowhead whale. Unpubl. report for the World Wildlife Fund for Nature Arctic Conservation Programs. Project No. BCV 50450. Available from World Wildlife Fund (Canada), 245 Eglinton Ave. E., Toronto, ON M4P 3J1

Johannessen OM, Bengtsson L, Miles MW, Kuzmina SI and others (2004) Arctic climate change: observed and modelled temperature and sea-ice variability. Tellus Ser A Dyn Meteorol Oceanogr 56:328-341 
Koski WR, Davis RA (1979) Distribution of marine mammals in northwest Baffin Bay and adjacent Waters, 1978. LGL Limited Environmental Research Associates, Toronto (for Petro-Canada, Calgary)

Koski WR, Zeh J, Mocklin A, Davis R, Rugh DJ, George JC, Suydam R (2010) Abundance of Bering-Chukchi-Beaufort bowhead whales (Balaena mysticetus) in 2004 estimate from photo-identification data. J Cetacean Res Manag 11:89-99

Laidre KL, Stirling I, Lowry LF, Wiig Ø, Heide-Jørgensen MP, Ferguson SH (2008) Quantifying the sensitivity of Arctic marine mammals to climate induced habitat change. Ecol Appl 18:S97-S125

LGL Ltd. (1987) Bowhead whale food availability characteristics in the southern Beaufort Sea: 1985 and 1986. Indian and Northern Affairs Canada, Ottawa

Murison LD, Gaskin DE (1989) The distribution of right whales and zooplankton in the Bay of Fundy, Canada. Can J Zool 67:1411-1420

NWMB (Nunavut Wildlife Management Board) (2000) Nunavut bowhead traditional knowledge study: final report 2000. Nunavut Wildlife Management Board, Iqaluit, NU. Available at www.nwmb.com/english/ resources/Bowheadreport1.pdf

Redfern JM, Ferguson E, Becker K, Hyrenback C and others (2006) Techniques for cetacean-habitat modeling. Mar Ecol Prog Ser 310:271-295

Reeves RR, Cosens SE (2003) Historical population characteristics of bowhead whales (Balaena mysticetus) in Hudson Bay. Arctic 56:283-292

Reeves RR, Mitchell E (1990) Bowhead whales in Hudson Bay, Hudson Strait, and Foxe Basin: a review. Nat Can 117:25-43

Reeves RR, Mitchell E, Mansfield A, McLaughlin M (1983) Distribution and migration of the bowhead whale, Balaena mysticetus, in the eastern North American Arctic. Arctic 36:5-64

Reutter BA, Helfer V, Hirzel AH, Vogel P (2003) Modelling

Editorial responsibility: Edward Gregr,

Vancouver, British Columbia, Canada habitat suitability using museum collections: an example with three sympatric Apodemus species from the Alps. J Biogeogr 30:581-590

> Richardson WJ, Fraker MA, Würsig B, Wells RS (1985) Behavior of bowhead whales Balaena mysticetus summering in the Beaufort Sea: reactions to industrial activities. Biol Conserv 32:195-230

Rogachev KA, Carmack EC, Foreman MGG (2008) Bowhead whales feed on plankton concentrated by estuarine and tidal currents in Academy Bay, Sea of Okhotsk. Cont Shelf Res 28:1811-1826

Ross WG, MacIver A (1982) Distribution of the kills of bowhead whales and other sea mammals by Davis Strait whalers 1820-1910. Unpubl. report for The Arctic Pilot Project, Petro Canada, Calgary. Available at http:// sirsi1.lib.ucalgary.ca/uhtbin/cgisirsi/?ps=UFf6msV79z/ UCALGARY/174660003/60/44/X

Thomson DH, Fissel DB, Marko JR, Davis RA, Borstad GA (1986) Distribution of bowhead whales in relation to hydro-meteorological events in the Beaufort Sea. Environmental Revolving Funds Report 28. Arctic Institute of North America, University of Calgary, Calgary. Available at http://sirsi1.lib.ucalgary.ca/uhtbin/cgisirsi/ ?ps=UFf6msV79z/UCALGARY/174660003/60/44/X

Transport Canada (2010) Government of Canada takes action to protect Canadian Arctic waters. www.tc.gc.ca/eng/ mediaroom/releases-2010-h078e-6019.htm (accessed 15 January 2011

US Department of Commerce, National Oceanic and Atmospheric Administration, National Geophysical Data Center (2006) 2-minute Gridded Global Relief Data (ETOPO2v2). Available at www.ngdc.noaa.gov/mgg/ fliers/06mgg01.html (accessed 10 July 2010)

WWF (World Wildlife Fund of Canada) (2003) Isabella Bay bowhead whale critical habitat stewardship program. Unpubl. final report 2002-2003 to Environment Canada. Available at World Wildlife Fund (Canada), 245 Eglinton Ave. E., Toronto, Ontario M4P 3J1

Submitted: January 24, 2011; Accepted: November 16, 2011 Proofs received from author(s): March 12, 2012 